\title{
Annuities and income withdrawal
}

Received: 30th November, 1999

\section{Richard Leigh}

is a pensions lawyer with the London office of Eversheds, having joined them in 1998. Before that he was with Bristol solicitors Burges Salmon. He has some 15 years' experience as a pensions specialist. After serving articles in Lincoln's Inn, he spent four years in London as a trust and property lawyer before moving west, first as a partner in a small high street practice, and then as an in-house lawyer for Allied-Lyons (now Allied Domecq). He soon became involved in pensions, joining the Association of Pensions Lawyers (APL) as a full member in 1985. In 1994 he returned to private practice as Head of Pensions at Bevan Ashford before joining Burges Salmon at the beginning of 1996. He founded and has been Chairman of the APL's Western Group, and is a member of the APL's Education and Seminars Committee. He is Chairman of the Western Regional Group of the NAPF and a former NAPF Council Member. He writes and speaks regularly.

Abstract This paper examines the nature of annuities in general, the requirements for annuity purchase currently applicable to pension arrangements in particular, and the current rules governing annuity deferral and income withdrawal. It concludes with a brief look at the case for reform. The paper was first presented at the Association of Pensions Lawyers Conference in November, 1999.

Keywords: annuity; annuity deferral; income withdrawal; income drawdown; pension schemes; personal pensions; AVCs; buy-out policies

\section{Introduction}

The provision of a pension through the medium of an annuity policy forms an essential part of the pensions framework in the UK. The vast majority of occupational schemes (apart from the larger self-administered final salary schemes and a few large money purchase schemes) choose, and all personal pension plans are required, ultimately, to provide pensions in this way.

Given an open and competitive annuity market it might be thought that the system would work well, and indeed until the decline in gilt yields that has taken place over the last few years, few complaints were voiced.

However, with that decline has come a decline in annuity yields, and a steadily increasing amount of criticism of annuities and their suitability as a means of delivering pension benefits. The income withdrawal rules, introduced by the Inland Revenue in an attempt to ease the perceived problems associated with the annuity requirements, have also come in for much criticism, and there now appears to be growing pressure for a more fundamental change in the rules.

This paper examines the nature of annuities in general, the requirements for annuity purchase currently applicable to pension arrangements in particular, and the current rules governing annuity deferral and income withdrawal. It concludes with a brief look at the case for reform.

\section{Annuities}

\section{Nature of an annuity}

Legal interpretation

In its broadest sense, an annuity may be defined simply as an annual payment of money made by one person to another. 
One rather ancient definition puts it quite succinctly:

'An annuity is a yearly payment of a certaine summe of money granted to another in fee, for life, or yeares, charging the person of the grantor onely'

(Co. Litt. 144b: see Wms. Exs., 12th ed., vol. 1, 503)

At its simplest, there would seem to be no distinction drawn between capital and income; indeed, there is a line of authority to the effect that where the donor of an annuity directs that it be purchased, or dedicates a fund out of which it is to be purchased, or where the annuity is dealt with as being in existence and operative beyond the life of the first annuitant and no other period can be fixed for such further duration short of making it perpetual, the annuity will be in perpetuity, ie, it is a bequest of such amount as will produce the income intended for the legatee, who may elect to have either the capital or the income (see eg Hicks $v$ Ross [1891] 3 Ch 499).

However, the distinction between capital and income is an important one from a tax viewpoint, and it is now well established that the term 'annuity' in tax legislation is used virtually exclusively (there is one exception, dealt with below) to describe a form of taxable income. In a leading tax case on the nature of a taxable annuity, Lady Foley $v$ Fletcher and Rose (1858) $3 \mathrm{H} \& \mathrm{~N} 768$, it was held that an annuity means "where an income is purchased with a sum of money, and the capital has gone and has ceased to exist, the principal having been converted into an annuity' (per Watson B). This definition was approved by Rowlatt J in Perrin v Dickson (1929) 2 $\mathrm{KB} 85$, who commented on the distinction to be drawn between an agreement to pay a debt by instalments, and an agreement for good consideration to make certain annual payments for a fixed number of years:

'The mere circumstance of a pre-existing debt is not the test, but whether the principal sum is liquidated or not. If it is liquidated, the annual payments made in consideration of the debt constitute an annuity. If the principal sum is not liquidated, but continues to exist and is repaid in annual instalments, the repayment does not constitute an annuity.'

Distinction between 'annuity' and 'pension' There seems to be no legal definition of a pension. The Concise Oxford Dictionary describes it as a 'periodic payment made esp. by government, company, or employer, in consideration of past service or on retirement etc.' On the basis of this, and of the decisions in Foley and Perrin, a pension can be said to be a type of annuity, regardless of who pays it. The provisions of some pension schemes even refer to the provision of an annuity by the scheme, for example, in respect of AVC funds when accepted by the scheme and converted to pension. In a pensions context, however, the term 'annuity' is usually used to describe an annuity policy issued by an insurance company, and the payments made under such a policy, even where such payments are in fact discharging the pension obligations of scheme trustees.

\section{Types of annuity}

Retirement ('compulsory purchase') annuity There is no legal definition of this type of annuity, but the term is widely used to refer to an annuity policy which complies with Inland Revenue requirements for the purpose of providing 'relevant benefits' (as defined in s.612(1) Income and Corporation Taxes Act 1988 ('ICTA 88') under an exempt approved pension arrangement. 
In s.612(1) 'pension' is defined as including 'annuity'.

\section{'Hancock annuity'}

A Hancock annuity is an immediate annuity purchased by an employer for an employee who is about to retire or who has already retired. Its name comes from Hancock v General Reversionary Investment Co Ltd [1919] 1 KB 25, which considered whether the cost of buying an annuity to replace an employee's pension which was previously paid direct by the employer was allowable against tax. If arranged properly, it will obtain all the normal tax advantages of an exempt approved scheme.

Strictly speaking, a Hancock annuity is an individual arrangement under which an employer's unfunded liability to pay a pension is converted to a funded immediate annuity after retirement by the purchase of an insurance contract. However, the term has come to mean any arrangement set up either at, after or shortly before retirement to provide benefits by means of an annuity policy, irrespective of whether any liability existed previously.

Hancock annuities may be provided through an exempt approved scheme, and scheme rules may provide for benefits to be given to former employees, even where they are not otherwise eligible for scheme membership, provided the benefits are 'relevant benefits' and are subject to normal Inland Revenue limits.

Immediate payment of benefits by way of a Hancock annuity is the only permissible way of providing retirement benefits for an employee retiring after the attainment of age 75 (see para 6.7 of the Inland Revenue Practice Notes (1997)).

\section{Purchased life annuity}

This is defined in s.657 ICTA 88 as 'a life annuity granted for consideration in money or money's worth in the ordinary course of business of granting annuities on human life'. A 'life annuity' is defined as 'an annuity payable for a term ending with (or at a time ascertainable only by reference to) the end of a human life, whether or not there is provision for the annuity to end during the life on the expiration of a fixed term or on the happening of any event or otherwise, or to continue after the end of the life in particular circumstances'. In other words, a purchased life annuity can be for life or any shorter or longer period. Excluded from the definition are annuities which:

- would (otherwise than under s.656 see below) be treated for tax purposes as consisting to any extent in the payment or repayment of a capital sum

- are purchased partly or wholly with money qualifying for relief under ss.266 (life assurance premiums), 273 (payments securing annuities for dependants), 619 and 622(3) (retirement annuity contracts)

- are purchased in accordance with directions in a will, or to provide for an annuity payable under a will or settlement out of income of property disposed of by the will or settlement

- are purchased in connection with any sponsored superannuation scheme under s.624 ICTA 88, any scheme approved under s.620, or in recognition of another person's services in any office or employment, or

- are payable under approved personal pension arrangements.

Purchased life annuities enjoy favourable tax treatment under s.656 (see below).

\section{Reversionary annuity}

This is simply an annuity which does not begin until the death of a specified 
person. In the context of retirement annuities this will normally be the scheme or plan member, when the annuity will normally be payable to a surviving spouse or dependant.

\section{Immediate/deferred annuity}

An immediate annuity is one which begins as soon as it is purchased; a deferred annuity is one which does not begin until an agreed future date (normally the intended retirement date of the annuitant).

\section{Single life/joint life annuity}

More accurately termed a joint life last survivor annuity, this latter is simply an annuity that is payable until the last of two annuitants dies. In the pensions context the amount of the annuity will usually reduce on the first death.

\section{Level-term annuities}

These pay a fixed amount in nominal terms for the life of the annuitant. The amount will normally be determined by reference to yields on government stocks ('gilts') or corporate bonds.

\section{Escalating annuities}

An annuity which increases annually either at a fixed rate (typically 3 per cent or 5 per cent) or by reference to an index, such as the Retail Prices Index. An annuity which increases by Limited Price Indexation is in this category. The starting rate tends to be much lower than the level-term annuity and it can take a long time before the total value of an escalating annuity outweighs that of a non-escalating annuity. Again, these annuities are usually based on the returns from gilts or bonds.

\section{With-profits annuities}

These allow the annuitant to improve income by taking on a degree of investment risk. Instead of relying on gilt yields, the pay-out depends on the level of bonuses declared each year by the chosen annuity company. With-profits annuities can be adapted in a variety of ways, for example by anticipating future bonuses and adding part of them to income in the early years. Although this type of annuity will usually provide a minimum level of guaranteed income, there is no guarantee of any increases. Most insurers offer a two-tier bonus system consisting of a 'reversionary' bonus which, once added to the pension, forms a permanent increase to the value of the annuity, and a terminal bonus which applies for a year at a time and fluctuates in value.

\section{Equitable Life v Hyman (HC 9 Sept 1999)}

This recent case has created a good deal of publicity and comment, and is worth examination. It concerned the question as to whether Equitable Life (EL) is entitled, when allocating final bonuses among its with-profits policyholders, to award reduced bonuses (or none at all) to policyholders whose policies contain guaranteed annuity provisions.

Between 1957 and 1988, EL issued a large number of with-profits annuity policies containing guaranteed annuity rates (GARs). It was accepted that the GARs were contractually binding on EL (who also issued a large number of with-profits policies without guarantees). At the time of issue, the GARs were at levels well below the then current annuity rates. By 1993, however, annuity rates had fallen below the level of the GARs, which by late in 1998 had become roughly 25 per cent higher than current rates. In order to mitigate this effect, in 1994 EL introduced a policy of declaring a reduced final bonus for those policyholders with GARs, such that they ended up with an annuity at the same rate as that applicable to the non-guaranteed policies. It should be 
noted that in no case was the actual guarantee breached. Not surprisingly, the policyholders with GARs complained, and EL were prevailed on to bring a test case, Mr Hyman acting as a representative policyholder, to determine the propriety of their actions. In particular, it was contended on behalf of Mr Hyman that EL were in breach of contract in awarding lower bonuses to the GAR policyholders, and that to do so was an improper exercise of EL's discretionary power to allocate bonuses.

The court held in favour of EL on both issues. The basis of the contract between EL and its policyholders was of course a key issue in the matter, and the court found that, as a matter of fact, EL's Articles of Association, which were binding on all policyholders, allowed EL to allot a final bonus on a conditional basis (ie, a final bonus of $\mathcal{E X}$ if a GAR-based annuity is taken, or of $\mathcal{E Y}$ if not). It was also accepted that the Articles gave the EL Board a very wide discretion in respect of the declaration of bonus, giving in particular the power to apportion surplus among the with-profits policyholders 'on such principles, and by such methods as they may from time to time determine'. In considering whether the Board had exercised that discretion properly, the Court followed the principles laid down in Edge $v$ Pensions Ombudsman [1998] Ch 512 and found, as a matter of fact, that it had, ie, that it had considered only relevant, proper and rational factors, had not failed to take into account any factors it should have taken into account, and that the decision was not one which reasonable directors, properly directing themselves, could not have reached.

A significant feature of the case was the fact that, in some of EL's published illustrations showing how the bonus system added value to a with-profits policy, comparing one with a GAR and one without, there was arguably an implication that the same final bonus would be added in each case. It was recognised that these illustrations had played a considerable part in fuelling the discontent of many policyholders, and the question arose as to whether the illustrations (along with EL's bonus practice up to 1994) created any 'reasonable expectations' in the minds of policyholders, and if so, whether that had any bearing on the exercise of the Board's discretion in relation to final bonus allocation. In the event, while the court was prepared to accept that the illustrations had created reasonable expectations, and that such expectations were certainly a relevant factor to be considered in the exercise of the Board's discretion, they did not amount to contractual rights, and were only one of the factors to be considered.

It is understood that the decision is being appealed by the GAR policyholders.

\section{Unit-linked annuities}

Here the underlying fund is invested in a range of unit-linked funds, and the units are sold to provide income. This gives the annuitant access to equity investment, allowing for a better rate of return on the fund over the long-term. It does, however, involve a higher level of risk and, usually, higher management charges in respect of fund management. Unit-linked funds are subject to more volatility than with-profits funds, which means the resulting income can increase or decrease according to market conditions. There is no guarantee as to the level of income.

\section{Investment-linked annuities}

These are structured in the same way as conventional annuities, except that the value of future payments fluctuates 
depending on investment returns instead of providing a guaranteed income. They can be single or joint life, with or without guarantee period and paid monthly. Income payments are recalculated each year and depend on the value of the underlying fund. Annuitants give up the guarantee of future income payments in expectation that the higher returns from equities will lead to higher income payments in the future.

\section{Phased annuities}

These are generally available on larger personal pensions, ie, with a fund of at least $f 100,000$. Here the annuitant uses the fund to buy a series of individual annuities over a period of years, each time locking a proportion of the fund into the annuity rate then current. This leaves the individual free to decide each year the amount of income and the options he wishes to exercise, including income withdrawal from the remaining fund.

\section{Taxation of annuities}

\section{Liability to income tax}

Annuity payments are normally taxable as income under Schedule D Case III, s.18 ICTA 88. However, where the annuity is purchased with funds from an exempt approved occupational pension scheme, s.597 ICTA 88 provides that payments are to be taxed under Schedule E.

\section{'Purchased life annuities' - s.656 ICTA 88}

Although these are taxable as income in the same way as other annuities, they enjoy special treatment, in that part of the annuity is treated as a return of capital; the purchase price of the annuity is amortised over its length, and the taxable amount in each year is reduced by the amortisation for the year.

\section{Annuities and occupational schemes}

\section{Introduction}

In the context of occupational pension schemes, the retirement annuity policy fulfils three functions:

— it provides scheme trustees with a secure means of meeting their obligations to make pension payments, where the policy is purchased as an asset of the scheme

- it provides scheme trustees with a means of discharging their obligations to make pension payments, where the policy is purchased as an asset of the member either: (a) as an alternative to short service benefit in certain circumstances (see below), (b) on a pension becoming payable under the scheme, or (c) on the winding-up of the scheme

- it provides scheme members with deferred benefits with an alternative destination for the payment of a cash equivalent transfer.

The link between annuities and pension schemes is an obvious one; historically, the vast majority of smaller schemes were established as insured schemes, with documentation often specifying that pensions were to be secured by annuity policies, to be purchased from the insurer concerned. This would seem to suggest that the practice was originally developed more with the interests of the insurer in mind than those of the scheme beneficiaries. However, the common justification for annuity purchase is that, where the scheme is small, it does not have a large enough pool of pensioners to allow it to take advantage of 'mortality drag' (see below). In other words, the purchase of an annuity from an insurer by the trustees of an ongoing scheme is - or should be - a genuine 
insurance-based step designed to cover risk.

\section{Inland Revenue requirements for immediate annuities}

\section{General}

With the exception of the rules relating to small self-administered schemes (SSASs), there is no express requirement, either in ICTA 88 or the Inland Revenue Practice Notes, for an occupational scheme to provide for pensions to be secured by annuity purchase. The official policy of the PSO is that it will not seek to impose any such requirement on a scheme, regardless of size. However, the Revenue makes it clear in the requirements for the approval of SSASs that the security of the pension promise is one of its prime concerns in considering whether to grant exempt approval and that annuity purchase is considered necessary where the 'pool' of members is small. It is hard to reconcile this with the PSO's policy on non-SSASs, many of which are actually smaller than some SSASs, particularly as the self-investment aspects of SSASs do not seem to have figured in the PSO's reasoning. In practice, of course, the vast majority of small occupational schemes are insurance company products, and invariably provide for annuity purchase in any event.

No distinction between final salary and money purchase schemes

In considering whether a scheme should provide pensions by means of external annuity purchase, a distinction could arguably be drawn between final salary schemes and money purchase schemes. The pensioners of the former have no direct interest in the underlying fund, which acts as a pool which can tolerate 'adverse experience', whereas those of the latter may arguably be viewed as owning a collection of individual 'pots' of money, leaving no room for pooling, and therefore no margin for adverse experience, so that the only safe course is to buy out the liability by means of annuities. However, this distinction is not strictly valid, since the allocation of value to individual members in a money purchase scheme is usually notional, with no entitlement to any part of the underlying assets. The PSO has said that it is content to leave the decision as to annuity purchase to the trustees and sponsors of individual schemes, and will not look at money purchase schemes any more closely than at final salary schemes.

\section{SSASs}

As noted above, because of Inland Revenue concerns over the size of SSASs, when the PSO first began to impose special controls over them in the shape of Memorandum 58 (published in Feb. 1979), they included the requirement that pensions should be secured when they became payable under the scheme by the immediate purchase from a 'life office' of non-assignable, non-commutable annuities in the name of the trustees. However, even then it was recognised that flexibility was needed to cope with fluctuating annuity costs, and allowance was made for annuity purchase to be deferred, initially for up to five years, provided the scheme rules allowed it and guaranteed the pension for five years. The rules dealing with deferral and income withdrawal are dealt with in more detail below.

\section{Buy-out policies}

These insurance policies, universally known as 'section 32 policies' because they were originally allowed to be 
treated as exempt approved pension arrangements by 5.32 of the Finance Act 1981, are single premium deferred annuity policies which either have exempt approved status (under s.591 ICTA 88), or which, since 1st July, 1994, are deemed to provide benefits which correspond with those of a 'hypothetical' approved scheme (s.591(2A) ICTA 88). This latter extension to the scope of buy-out policies is a consequence of the EC Third Life Directive and ss.107 and 143 Finance Act 1994. The PSO will give voluntary clearance if there is doubt about whether a policy corresponds.

Buy-out policies as a transfer-out option for scheme members

Under s.94 Pension Schemes Act 1993 (PSA93), most members of occupational pension schemes have the right to have a transfer value (cash equivalent) applied to the purchase of an annuity which falls into the above category. The detailed provisions are too lengthy to set out in full in this paper, but may be found in ss.95-98 PSA93 (as amended) and paragraphs $10.42-10.51$ of the Inland Revenue Practice Notes. The latter specify both the PSO's essential requirements for a buy-out policy and those elements which are optional. Under Regulation 9 of the Occupational Pension Schemes (Preservation of Benefit) Regulations 1991 (SI 1991/167), the policy can provide different benefits to those provided by the scheme, as a permitted alternative to short service benefit, subject to a number of conditions set out in SI 1985 No. 1929. Where the benefits to be bought out include contracted-out rights, additional requirements apply; these are set out in the Contracting-out (Transfer and Transfer Payment) Regulations 1996 (SI 1996/1462).
Buy-out policies as a transfer-out option for trustees

The trustees of an occupational scheme can (if their scheme rules permit) have power to buy out benefits without the consent of the member in certain circumstances, detailed in the 1991 Preservation of Benefit Regulations mentioned above, broadly where the scheme is being wound up, or where the member has less than five years' 'qualifying service', and certain conditions are satisfied. This paper does not provide a detailed consideration of the relevant rules.

\section{Equal treatment}

In the landmark Coloroll case in 1994, the ECJ confirmed its ruling in Neath $v$ Hugh Steeper Ltd (Case C-152/91), that the use of actuarial factors in final salary schemes which differ according to sex did not infringe Article 119. The important principle was equality of funding.

It should, however, be noted that the Personal and Occupational Pension Schemes (Protected Rights) Regulations 1996 require the rate of a pension or annuity which gives effect to protected rights to be determined without regard to the sex of the member (Regulation $4(2)$ ).

\section{Annuities and personal pensions}

\section{Retirement annuity contracts}

These are retirement annuity policies which have been approved under what is now Part XIV Chapter III ICTA 88, which covers ss.618 to 629 . They are of course more commonly known as 's.226 annuities', because they were first approved under s.226 of the Income and Corporation Taxes Act 1970. No new approvals have been possible for such 
contracts since 1st July, 1988, when they were superseded by personal pensions; however, contracts already approved and in force on that date are still valid. The annuity requirements are broadly similar to those now applicable to personal pensions (see below). They must provide for an annuity for the life of the policyholder to begin not earlier than age 60 - cf personal pensions (except on grounds of ill-health or special occupation) nor later than age 75 , and for no other payments to be made except a survivor's annuity (payable either to a spouse or one or more dependants on the member's death) of no more than the member's annuity entitlement, a guarantee of up to ten years in respect of any annuity, assignable by will or on intestacy, and a lump sum of up to three times the remaining annuity. There is also scope for a lump sum payable on death before 75 . No annuity is to be commutable, assignable or surrenderable. There is no scope for income withdrawal before the annuity is purchased.

\section{Personal pensions}

\section{General}

As can be seen from the following paragraphs, unlike the position in relation to occupational schemes (SSASs apart), the requirements for personal pensions to be secured by annuity purchase are specifically detailed in ICTA 88 .

However, the Revenue also have a discretion in the matter, which can be used to create further restrictions than those set out in the legislation, and Inland Revenue Guidance Notes IR76 (the latest version of which was published on 30th September, 1999) contains a fuller description of Revenue requirements.

\section{Revenue requirements}

S.631(2) ICTA 88 provides:

'The Board may at their discretion grant or refuse an application for approval of a personal pension scheme, but their discretion shall be subject to the restrictions set out in ss.632 to $638 \mathrm{~A}^{\prime}$

\section{S.633(1) ICTA 88 provides:}

'The Board shall not approve a personal pension scheme which makes provision for any benefit other than:

(a) the payment of an annuity satisfying the conditions in s.634 [or income withdrawals with respect to which the conditions in s.634A are satisfied];

(b) [lump sum for member];

(c) the payment after the death of a member of an annuity satisfying the conditions in s.636 [or income withdrawals with respect to which the conditions in s.636A are satisfied]

(d) [lump sum death benefit];

(e) [lump sum contribution refund].'

S.634 applies conditions to the member's annuity:

'(a) The annuity must be payable by an authorised insurance company which may be chosen by the member' (s.634(1)).

An authorised insurance company is defined in s.659B ICTA 88 as being one of the following:

(i) a person authorised under ss.3 or 4 of the Insurance Companies Act 1982 (or any similar previous enactment) to carry on long term business (as defined in that Act);

(ii) a friendly society (within the meaning of the Friendly Societies Act 1992) carrying on long term business;

(iii) an EC company (as defined in the Insurance Companies Act 1982) which lawfully carries on long term business 
or provides long term insurance in the UK, and which meets certain requirements designed to ensure that there is a presence in the UK that is accountable to the Revenue.'

The words 'which may be chosen by the member' introduce the concept of the open market option. It would appear that they are overriding, but the wording is a little ambiguous, and could conceivably be intended simply to be permissive, merely allowing the member the option to select the insurer if the rules of the personal pension scheme so provide. In practice, however, it is an academic point; market forces ensure that virtually all personal pension providers now allow for an open market option in any event (although in some cases members pay for using it).

The other conditions in s.634 are:

'(b) The annuity may not start before the member reaches age 50 , or after he reaches 75 , but it can start earlier if: (i) it is payable on the member becoming "incapable through infirmity of body or mind of carrying on his own occupation or any occupation of a similar nature for which he is trained or fitted" (s.634(3)(a)), or

(ii) the Revenue are satisfied that his occupation is one in which "persons customarily retire before that age" (s.634(3)(b)). A list of such occupations with the applicable retirement ages agreed by the Revenue may be found in Appendix 10 to Inland Revenue Guidance Notes IR76 (1999).

(c) The annuity must be payable for life (s.634(4)), or for a "term certain not exceeding 10 years" if longer (s.634(5)). It will be treated as payable for a term certain, even if it is to end earlier on either the marriage of the annuitant, his reaching 18 , or the end of his full-time education (if later). (d) With exception of an annuity for a term certain, which can be assigned on the death of the annuitant (either by will, or by the personal representatives on an intestacy), the annuity must not be capable of assignment or surrender (s.634(6))'

S.636 applies conditions to a survivor's annuity:

- The annuity must be payable by an authorised insurance company 'which may be chosen by the member or the annuitant' (s.636(1)).' The same comments apply here as to paragraph (4) (a) above.

- The annuity is only payable to the member's surviving spouse or dependant. Unless there is a protected rights annuity payable to a surviving spouse as of right, however, there is no compulsion to provide a survivor's annuity.

- The annuity must not be more than either the member's annuity (if one was being paid), or the amount which would have been payable to the member (ignoring any right to commute part of it for a lump sum) had it been purchased on the day before he died.

- The annuity must be for the life of the annuitant, or 'term certain not exceeding 10 years', but:

(i) it can cease on marriage;

(ii) it must cease at end of the annuitant's minority (or later end of full-time education); and

(iii) special rules apply for young spouses:

- a spouse under 60 may defer the start of the annuity to his/her 60th birthday or the later expiry of a guarantee period;

- where a spouse is under 45 and there are dependant children, the annuity may be designed to stop when the 
last child reaches 18 , provided the spouse is still then under 45 .

- Similar rules apply in relation to assignability and surrenderability as to annuities for the member (see para (4)(d) above).

\section{Annuities and contracting-out}

\section{Protected rights}

As for personal pensions, there are specific rules requiring annuity purchase in relation to protected rights under s.10 PSA 93 but they differ from those governing personal pension annuities. The detailed requirements are set out in s.29 PSA 93 and the Personal and Occupational Pension Schemes (Protected Rights) Regulations 1996 (SI 1996/1537):

- the annuity may not start before the member's 60th birthday, and there is no provision for an earlier date in special circumstances (such as poor health or employment in a particular profession);

- in the case of protected rights from a personal pension, the annuity must start no later than the member's 75th birthday, or (where relevant) the surviving spouse's 75 th birthday if sooner;

- in the case of protected rights from an occupational scheme, the annuity (or the pension if no annuity is required - the scheme may pay its own pensions) may not start later than the member's 65th birthday without the member's agreement;

- in respect of protected rights that accrued before 6th April, 1997 (including converted GMPs):

(a) the annuity must provide for annual increases by at least the same rate as is applicable to GMPs under s.109 PSA 93 (broadly 3 per cent Limited Price Indexation ('LPI')), but no more than 3 per cent;

(b) the annuity must be based on unisex rates, and without regard to marital status.

- in respect of protected rights that accrued after 5th April, 1997

(including converted s.9(2B) rights):

(a) the annuity must provide for annual increases by 5 per cent LPI (in line with the requirements of the Pensions Act 1995);

(b) it must be based on unisex rates, and it must be assumed that the member will die leaving a surviving spouse, unless the member is unmarried and agrees to the rate being determined on his/her own life only;

- the annuity must be payable for the member's life, and after death, it must continue to be paid at half the rate to which the member would have been entitled if alive, to a surviving spouse who either:

(a) is receiving child benefit in respect of one or more children of the marriage, or is living with such child or children who are under 16 ; or

(b) was 45 or over either when the member died, or during a period when the circumstances in (a) existed.

The annuity must continue until either:

- the circumstances in (7)(a) above no longer exist, and the spouse is under 45; or

- the spouse remarries under pensionable age; or

- the spouse dies

- the annuity may continue for five years after the death of the member at the rate which would have been payable to him; 
- if there is no surviving spouse, an annuity of the same amount may be paid to 'any one person', or to any child or children in respect of whom the member was entitled to child benefit, until 18, or following the death or majority of any such annuitant, to 'any one person' for a period within five years of the start of their annuity.

\section{Guaranteed minimum pensions (GMPs)}

A previous section above deals with the ability of schemes to buy out their liability to provide contracted-out rights, including GMPs. Where GMPs come into payment, the trustees of the scheme may be required by the scheme rules to purchase an annuity, or they may pay the GMP from the assets of the scheme. If the former, they must ensure that any annuity secures the benefit promise precisely; in such circumstances the annuity is not a buy-out of the trustees' liability, but is an asset of the scheme, securing that liability. Although liability to pay GMPs can be deferred to age 75 (subject to rules requiring the amount to be increased) there is no scope for bringing a GMP into payment prior to SPA.

\section{Accrued rights under s.9(2B) Pension Schemes Act 1993 s.9(2B)}

A previous section above deals with the ability of schemes to buy out their liability to provide contracted-out rights. Securing such rights when they come into payment are integral to the benefit structure of the scheme that provides them, and if annuity purchase is required or selected under the rules of the scheme, the trustees will remain liable for the provision of the scheme benefits, in the same way as noted above. In contrast to GMPs, s.9(2B) rights can be taken early, however, in line with normal Revenue requirements (ie, from 50 or earlier if through incapacity etc).

\section{Perceived disadvantages of annuities}

\section{Introduction}

The use of annuities as a compulsory means of providing pensions is seen by many as suffering from several disadvantages:

— the 'pooling' effect, while purportedly cost efficient, is claimed by some as unfair, in that it produces winners and losers in individual cases, according to longevity;

- the purchase cost is highly sensitive to gilt prices prevalent at the date of purchase, leading to inequalities caused by price changes;

- there is a difference in valuation approach between annuity pricing and the calculation of cash equivalents in respect of final salary benefits, leading to inequality of treatment as between transfers to other pension schemes, and transfers to buy-out policies or outright annuity purchase;

- the annuity market is claimed not to be an efficient one, with the result that prices and options are not competitive. Annuities and the 'pooling effect'

\section{Mortality tables}

On the face of it, the provision of a pension for life involves a gamble, irrespective of whether the provider is a large final salary scheme, or an annuity purchased with the proceeds of a personal pension. Leaving aside market factors, the amount of pension or annuity that can be paid fundamentally depends on the life expectancy of the pensioner/annuitant at the time the amount is calculated, a 
factor which is determined primarily by reference to tables drawn up by the actuarial profession, based on statistical experience. Given tables that are reasonably accurate, the average amount paid out by way of pensions or annuities over time should equate to the capital allocated for the purpose, after taking investment returns into account and allowing for the insurance company's margin. Funding costs for final salary schemes (and thus the transfer values in respect of final salary entitlements) are calculated using similar principles.

\section{'Mortality drag'}

Inevitably, individual experience virtually never matches the average; some people will live longer than expected, resulting in them making a profit from their longevity, while others will die earlier than expected, with the opposite result. This has the effect of creating a cross-subsidy within a 'pool' of lives, consisting of either the pensioner population of a large pension scheme or the annuitant population of a particular insurance company. Furthermore, as an individual gets older, his life expectancy becomes extended. This effect is known in the actuarial profession as 'mortality drag'.

\section{Guarantees}

It is of course possible to purchase an annuity with up to ten years' payments guaranteed in the event of premature death, although the guarantee inevitably increases the cost of the annuity.

\section{The arguments for and against 'pooling'}

Pooling is cited as one of the advantages of the system, in that it reputedly keeps the overall cost of pension provision lower than it would otherwise be by spreading the risk. It is not confined to annuities, of course; large pension schemes (predominantly the final salary variety) which pay pensions from their own assets also take advantage of pooling.

The provision of a 'secure income for life' is a requirement of the Inland Revenue if approval is to be given to any pension arrangement, an approach which perforce rules out any element of capital provision (apart from the concessionary tax-free lump sum). On that basis, there seems to be no alternative to the present system. However, there seems to be increasing pressure for change, fuelled largely no doubt by the poor annuity rates currently available. It is argued that the cash equivalent of a scheme member's accrued pension entitlement represents the capital value of deferred pay (following the Barber decision), and that the member should therefore be entitled to receive the full value of that entitlement. The requirement that the money be used to purchase an annuity, while offering the chance of gain if the member lives a long time, puts the member at risk of not receiving full entitlement if he dies prematurely. Of course, the counter-argument (and it would seem the correct one) is that, given an open market purchase, the value of the annuity does indeed reflect the full value of the member's entitlement, in that it represents the true market cost of providing a given amount of income for life. However, this leaves open the question as to whether the member should be forced to purchase an annuity with his pension fund.

\section{The current cost of annuities}

It is widely known that annuity rates have declined in recent years; in broad terms they have fallen by about half in the last decade or so. The reason for this decline lies in the fact that insurance 
Table 1: Best annuity rates available at $\mathbf{2 2 . 1 0 . 9 9}$ per $£ 10,000$

\begin{tabular}{llll}
\hline & $\begin{array}{l}\text { Level, without } \\
\text { guarantee }\end{array}$ & $\begin{array}{l}\text { Level, five-year } \\
\text { guarantee }\end{array}$ & $\begin{array}{l}\text { Escalating @ 5\%, } \\
\text { no guarantee }\end{array}$ \\
\hline Male, age 60 & 814.80 & 806.16 & 487.32 \\
Female, age 60 & 723.84 & 720.96 & 401.28 \\
Joint life (M60/F55) & 645.00 & 645.00 & 322.00 \\
\hline
\end{tabular}

Source: Money World.

companies have generally funded their annuity obligations by investing the annuity purchase monies in predominantly medium-dated government stocks (gilts), for reasons of stability. The yield on such securities, never startling even at their best, has declined in recent years, broadly in line with the drop in interest rates and inflation. An additional factor, aggravating the decline, has been a recent and growing shortage of suitable gilts, resulting in price increases. This is largely due to the fact that gilts are the prime means whereby the government borrows money, yet the public sector borrowing requirement is at a record low. In fact, annuity rates have eased a little over recent weeks (see Table 1 for current rates), but they still represent poor value when compared with the returns available from equities.

\section{Income withdrawal}

\section{Introduction}

The facility to withdraw income from a pension plan while deferring annuity purchase is a relatively recent development, and is principally a response to the problems associated with the decline in gilt yields which began about a decade ago. From its origins in the SSAS rules, it was later introduced to the rules governing personal pensions, and finally was extended in June 1999 to contracted-in occupational money purchase schemes. It has no application to final salary schemes or contracted-out schemes.

\section{Small Self-Administered Schemes (SSASs)}

Annuity deferral for member for up to five years since about 1980

The idea of deferring the purchase of an annuity first evolved with the development of the rules surrounding small self-administered schemes, where the Revenue insist that the pension must ultimately be secured externally by annuity, in recognition of the fact that such schemes are by their nature unlikely to be able to provide a large enough pool of lives to provide adequate security for the pensioner. The PSO have therefore recognised for some time that the timing of the purchase should be flexible to account for the fact that since:

- annuity rates fluctuate

— investment yields fluctuate

- while capital values may be temporarily low, income yields may be high,

the trustees should not be 'forced' into a sale.

The PSO have therefore allowed annuity purchase to be deferred (and, if appropriate, phased) while the pension is paid directly from the fund, for almost as long as SSASs have been subject to special regulation. Originally the option 
to defer lasted for only five years from the retirement date specified in the scheme, but this was extended to age 75 in 1994. The PSO requires regular consideration of whether it is appropriate to defer purchase of the annuity until then.

\section{Extension to survivors in 1995}

In PSO Update No. 7 (23rd August, 1995) the option to defer annuity purchase was extended to widow(er)s and dependants, where the member died in service or retirement. Deferral can be until the annuitant reaches age 75 , or, if earlier, the date when the deceased member would have reached that age.

The same requirements for review (as for deferral for a member) apply as appropriate.

A widow(er)'s/dependant's pension will normally be purchased with the member's pension. However, if the pension is payable to whoever is the spouse/ dependant at time of death that pension may be purchased at time of death.

\section{Actuarial certification of pension payable}

Where the pension is paid directly from the fund, the scheme actuary must certify the amount payable in accordance with scheme rules taking into account any contingent dependant's pensions payable and the scheme's income and assets, particularly those notionally linked to the member's benefits. The actuary will be required to provide an explanation if the amount differs from an open market rate by more than 10 per cent.

\section{Self-investment implications}

- The value of any pension payable must be excluded from fund for self-investment purposes;

- where all members and any widow(er)s/dependants are drawing a pension from the scheme the PSO will not allow any new loans or share purchases in the employer or associated employer after the first payment of the final retiring member's pension. If no member reaches retirement, the rule applies to the final widow(er)s or dependant. Where there are existing such loans or investments, then they should be realised within five years.

\section{Rule changes}

Annuity deferral must be permitted under the rules of the scheme. Note that the PSO will not accept a rule change allowing annuity deferral in respect of a member who has retired.

\section{Personal pensions}

While it has always been possible to defer annuity purchase to age 75 under a personal pension plan, the concept of income withdrawal was introduced only in 1995 by section 58 and Sched 11, FA 1995 (now part of ICTA 88).

The facility applies only to personal pensions which:

— are tax approved, and

- contain the appropriate provisions.

S.633(1) ICTA 88 provides:

'The Board shall not approve a personal pension scheme which makes provision for any benefit other than:

(a) [the payment of an annuity satisfying the conditions in s.634 or] income withdrawals with respect to which the conditions in s.634A are satisfied;

(b) [lump sum for member];

(c) [the payment after the death of a member of an annuity satisfying the conditions in s. 636 $o r$ income withdrawals with respect to which the conditions in s.636A are satisfied;

(d) [lump sum death benefit];

(e) [return of contributions on death].' 
S.634A imposes conditions on income withdrawal by a member:

- No withdrawal before the member attains age 50 (except in the case of incapacity, or where an early pension date applies to the member's occupation), or after age 75 .

- Amount of annual withdrawal must not exceed the maximum amount of annuity purchasable by the member on the 'relevant reference date' (ie, the member's pension date, and every third anniversary of it).

The maximum annuity purchasable by the member is based on the cost of a level single life annuity, and is calculated by reference to a set of tables compiled by the Government Actuary's

Department (GAD):

- Minimum withdrawal may not be less than 35 per cent of the maximum.

- The amount is variable annually within minimum and maximum limits.

- The calculation must be repeated at each 'relevant reference date'.

- The right to income withdrawal must not be capable of assignment or surrender.

- After income withdrawal starts:

- no transfers in or out of the personal pension scheme are permitted (s.638(7A)(a) ICTA 88);

- no further contributions are possible, other than 'minimum contributions' from the Department of Social Security (s.638(7A)(b) ICTA 88).

Income withdrawal after member's death conditions (s.636A) include:

- If someone is entitled to an annuity following the death of the member, they can elect to defer it and take income withdrawal until the earliest of:

— their 75th birthday;

- the date of the member's 75th birthday;

- the termination of their entitlement (eg on remarriage).

- Income withdrawal is obviously not available where the member had already bought an annuity with the fund, nor is it available to a surviving spouse who has deferred the purchase of an annuity to their 60th birthday (or later termination of a guaranteed period).

- The minimum and maximum amounts that can be withdrawn are calculated in the same way as for the member (see above), but the available fund may have to be restricted to comply with the rule that the survivor's annuity may not exceed the amount of the member's annuity (s.636(3)(b) ICTA 88).

- The right to income withdrawal must not be capable of assignment or surrender.

- As an alternative to annuity purchase or income withdrawal, the dependant may opt to take his entitlement as a cash lump sum, less 35 per cent tax.

- If there is more than one dependant, each one may choose independently of the other(s) whether to take annuity, withdrawal or lump sum.

- On the death of a dependant during a period of annuity deferral, the fund is payable as a lump sum under discretionary trusts, subject to 35 per cent tax.

\section{Money purchase schemes}

Insured schemes and buyout contracts have been informally permitted to provide for annuity deferral and pension payment facilities on the same basis as SSASs since 1996. 


\section{PSO Update No. 54}

On 30th June, 1999 annuity deferral and income withdrawal facilities were extended to:

- all contracted-in money purchase occupational schemes (regardless of whether they are required by their rules to buy annuities), including money-purchase-based SSASs;

- money-purchase-based AVCs and FSAVCs;

- money-purchase-based buyout policies.

Contracted-out arrangements were excluded from the facility.

The rules governing income withdrawal are similar to those for personal pensions, but the following points should also be noted:

- The rules are not set out in statute; they are governed by the Revenue's discretionary practice.

- Schemes and policies are likely to require amendment before the facility can be used; the Revenue has said that it will permit the facility to be used in advance of amendment, provided an announcement is first made to members, and the formal amendment is made within 12 months of the facilities first being made available.

- Funding checks are needed both at the time income withdrawal starts, and again when the annuity is finally purchased (but NB AVC arrangements - see below), to ensure that

Revenue limits are not exceeded, and any surpluses must be dealt with in accordance with normal Revenue rules. Before starting income withdrawal, the member or survivor must select the benefits they want, ie level or escalating pension, with or without guarantee (in the case of the member). The trustees or provider must then apply an appropriate market rate for those benefits, ignoring any allocation to survivors' pensions for this purpose.

- The amount of income withdrawn must comply with the same minimum/maximum rules applicable to personal pensions, by reference to the same GAD tables (regardless of the benefits selected), but it must also not exceed Revenue maximum limits in respect of the member or beneficiary concerned; this requirement overrides the 35 per cent minimum withdrawal rule (see above).

- On the death of the member during income withdrawal, the balance of a five-year guarantee may be paid (if it was selected by the member), based on the maximum permitted at the start of the withdrawal, and the payment may make up for any difference between that and the amount actually drawn. Anything left in the member's fund may be used to provide survivors' benefits, and the survivor(s) may also elect for income withdrawal. The cash lump sum option is not available.

- On the death of the survivor while withdrawing income, any funds remaining must be dealt with in accordance with the scheme rules.

\section{AVCs}

Until 30th June, 1999, AVC benefits had to be taken at the same time as other benefits under the scheme. Under the new rules set out in PSO Update 54, provided scheme rules permit, AVC and FSAVC benefits may now start at any time between age 50 (or earlier if a person leaves employment through incapacity) and age 75 , regardless of 
whether the member retires or leaves service then. He may also continue making AVC payments, even after opting to take benefits (subject to the normal rules).

\section{Provision of AVC benefit prior to start of main scheme benefits}

This must be by way of income withdrawal, not annuity purchase, and cannot be in the form of a lump sum, even where the AVC pre-dates the April 1987 change in the rules (the member must wait until he takes his main scheme benefits for this purpose). The income withdrawal rules are as for money purchase schemes (see above). A maximum benefits check is made when the main scheme benefits come into payment, and any surplus AVCs repaid. The member can then choose to continue income drawdown, or secure the AVC pension by annuity purchase.

Provision of AVC benefit at same time as main scheme benefit

The member can choose to take his AVC benefits and his main scheme benefits in any combination of annuity purchase and income withdrawal (always assuming the main scheme benefits are money purchase).

Deferral of AVC benefit until after start of main scheme benefit

There will be no entitlement to a lump sum from the AVC fund when the deferred benefits do come into payment, but a pre-'87 AVC member may take cash at the time the main scheme benefits become payable, and defer the residue. Where the lump sum entitlement is geared to the initial amount of pension, then deferral of the AVC benefit will reduce the entitlement. Again, the member can choose to take AVC benefits by means of income withdrawal or annuity purchase.

\section{Inland Revenue limits}

Limits checks must always be carried out when the main scheme benefits are payable, regardless of when the AVC benefit is paid. AVC benefits in payment are taken at their current value; otherwise, the current value is taken as the amount of annuity which the AVC fund could purchase, using GAD tables, at the time the main scheme benefits become payable. Special rules apply to controlling directors and higher earners, and the annuity value of any deducted lump sum has to be counted.

\section{Death of member}

If this occurs before taking main scheme benefits, the scheme's death-in-service rules will apply. If the member had started receiving AVC benefit, the remaining AVC fund can either be dealt with as a return of contributions with interest, or used to buy a survivor's pension. If no AVC benefit has been taken, any survivor will have drawdown options in the normal way.

If death occurs after taking main scheme benefits the scheme's rules on death in retirement will apply.

\section{Contracting-out: Protected Rights (personal pensions only)}

Income withdrawal in respect of protected rights is governed by sections 28(1A) and 28A Pension Schemes Act 1993 (inserted by Pensions Act 1995) but is only permitted between ages 60 and 75.

Broadly the same calculation method is used as for income withdrawal generally, but different GAD tables are used, based on unisex rates. Protected rights under an occupational scheme are excluded from these rules. 


\section{Perceived disadvantages of income withdrawal}

\section{Fund has to work harder}

As has been seen, annuity rates make allowance for the incidence of future mortality. So investment performance under income withdrawal has to outperform that of gilts underlying annuities, simply to keep pace. The amount of extra performance needed increases with age, running from about 2 per cent at age 65 to about 7 per cent at 75 , depending on the mortality tables used (source: Bacon \& Woodrow). On top of this is the fact that expenses are likely to be higher where income withdrawal is concerned, due to added administration and the cost of advice. The obvious way to achieve the extra performance needed is by investment in equities, but that of necessity involves greater risk.

\section{Requirement to buy annuity at 75}

Although annuity deferral was intended to allow scope for individuals to bide their time and wait for an improvement in annuity rates, the requirement to buy an annuity at 75 means a risk that an already depleted fund will have to be spent on buying an annuity at a potentially even worse rate than may originally have applied. Some economists predict further falls in gilt yields over the next few years, driven by lower interest rates in the EC, low inflation and a continuing drop in public-sector borrowing.

\section{Complex decision for member to take}

The 'pros and cons' of income withdrawal are difficult for the layman to understand without expert help and advice, which of course comes at a cost. Most experts in this field agree that it is not a realistic proposition for anyone with less than about $£ 100,000$ in their personal pension fund, and is best suited to high-net-worth individuals who are in the habit of taking sophisticated advice about their finances. It is not seen as a solution for the majority of scheme members (the average individual fund value has been estimated to be no more than about $\left.\mathcal{f}^{3} 3,000\right)$, and even less attraction to members of occupational schemes in general, and AVC holders in particular.

\section{Disadvantages for occupational money purchase schemes}

The added administration and expense of providing deferral and withdrawal facilities are likely to deter the majority of occupational schemes from making them available. In addition, the restrictions imposed by the benefit-checking rules and the inability to take the fund on the member's death during withdrawal (cf. personal pensions) act as further disincentives. There is also a fear that members who make the wrong decision will try to blame scheme trustees for the fact, even where they have excluded themselves from any responsibility.

\section{Conclusions}

\section{Is a new approach needed?}

The public perception (fuelled by the media and the politicians) that annuities currently represent poor value for money has undoubtedly led to pressure for change. It is probably true that falling interest rates and gilt yields have turned annuities into disappointing investments, and that there is a case for development of new types of annuity, creating a balance between the need for security on the one hand and the need for better value on the other. However, annuities play a vital and valuable role in pension delivery, and no-one has yet succeeded in coming up with an alternative that 
delivers the same product - a steady stream of income for life - in a more effective way.

There are two options for change:

- changes within the existing legal framework; and

- changes to the existing legal framework.

\section{Changes within the framework}

There are some initiatives currently in development by the life insurance industry, many based around the concept of a with-profits annuity, providing a basic level of guaranteed return, with the prospect of (modest) bonuses derived from the insurer's investment performance. However, the bonus system is far from transparent and these products suffer from a poor public image. One or two insurers are currently looking at an investment-linked model which contains both a gilt element and an equity element, in an effort to create a similar two-tier structure of security and profit. Another potential development is the 'open annuity', a concept whereby the features of income withdrawal are built into an annuity policy, with certain safeguards. The Revenue have confirmed that in principle they have no objection to investment-linking, as long as it does not defeat the concept of a secure income for life.

Steps could be taken to improve the liquidity of the gilt market, and thereby increase the yields available. This is a more difficult area, since it needs political will to achieve, but in theory it would be possible for the government to issue a specially designed annuity or pension gilt, possibly indexed at LPI, aimed specifically at this market. Whether this is a realistic prospect is not for a mere lawyer to say, but the case in favour seems to be a good one.

\section{Changes to the framework}

Possible changes include the following:

— Extension/removal of age 75 limit;

— extension of ten-year guarantee;

- further relaxation of income withdrawal rules;

- permitting payments of capital, subject to tax.

The Inland Revenue is currently considering a range of possibilities, including the above, and it is expected that a report, and possibly some changes, may emerge towards the end of 1999. However, what, if anything, will actually be decided upon is, at the time of writing, impossible to say. 